\title{
EPITHELIAL CELL ASSOCIATION AND HYDROPHOBICITY OF YERSINIA ENTEROCOLITICA AND RELATED SPECIES
}

\author{
D. A. Schiemann and Pamela J. Swanz
}

\section{Department of Microbiology, Montana State University, Bozeman, Montana 59717. $U S A$}

\begin{abstract}
SUmmaRY. Six of 11 test strains of Yersinia enterocolitica and related species that carried other markers of pathogenicity were found to associate with Henle 407 epithelial cells in vitro. All Henle-positive strains were hydrophobic when tested by hydrophobic interaction chromatography with phenyl-Sepharose and by partitioning in an aqueous-hexadecane mixture. Hydrophobicity was also exhibited by some of the Henle-negative strains. None of the test strains aggregated in low concentrations of ammonium sulphate, suggesting that protein structures such as fimbriae were not involved in hydrophobicity or epithelial cell association.
\end{abstract}

\section{INTRODUCTION}

The interaction of Yersinia enterocolitica with epithelial-cell cultures in vitro was first described by Lee et al. (1977) and Une (1977), who observed bacteria within stained monolayers by microscopy. Okamoto et al. (1980) used a similar technique and electronmicroscopy to observe adherence of bacteria to the external surface of epithelial cells. Devenish and Schiemann (1981) developed a technique for quantitative expression of infectivity to HeLa cells based on viable cell counts, and related a relative index of infectivity to other virulence indices (Schiemann and Devenish, 1982).

Strains of $Y$. enterocolitica infective for HeLa cells do not exhibit fimbriae by electronmicroscopy (Rahimian and Evans, 1981; Schiemann and Devenish, 1981). Old and Robertson (1981) showed that production of mannose-resistant fimbrial haemagglutinins by $Y$. enterocolitica did not correlate with the ability to adhere to epithelial cells.

Several reports relate the adherence properties of bacteria to hydrophobic characteristics. Smyth et al. (1978) reported that hydrophobicity of porcine strains of Escherichia coli was related to the presence of the K 88 fimbrial adhesin. Wadstrom et al. (1980) subsequently showed that hydrophobicity depended on the presence of other fimbrial adhesins on $E$. coli, which in turn determined the ability of the bacteria to adhere to intestinal epithelial cells. Lindahl et al. (1981) used aggregation in ammonium sulphate to indicate hydrophobic properties of bacteria, and related this "salting out" to the presence of fimbrial antigens on E. coli. Rosenberg et al. (1980) described a method based on hydrocarbon adherence for measuring cell-surface 
hydrophobicity, which was used to relate adherence to the presence of fimbriae on Acinetobacter calcoaceticus (Rosenberg et al., 1981 and 1982) and to smooth and rough forms of Proteus mirabilis (Rosenberg et al., 1982).

Two reports are available on hydrophobic properties in $Y$. enterocolitica. Faris et al. (1983) observed that mannose-resistant haemagglutination was related to the presence of fimbriae and hydrophobicity as measured by hydrophobic interaction chromatography and aggregation in ammonium sulphate. Lachica and Zink (1984) used binding of cells to polystyrene and xylene and binding of ribosomes to nitrocellulose filters to observe that hydrophobicity was plasmid- and temperaturedependent. In this paper we describe the relationship between hydrophobicity in $Y$. enterocolitica and related species and the ability to associate with Henle 407 intestinal epithelial cells in vitro.

\section{MATERIALS AND METHODS}

Bacteria. Eleven strains of $Y$. enterocolitica or related species were investigated. All were isolated from human faeces except $Y$. enterocolitica E887, which was isolated from a monkey, and $Y$. kristenseni $\mathrm{E} 812$ and $Y$. intermedia E814, which were isolated from pork.

The strain of $P$. mirabilis used as a control culture for measuring hydrophobicity by hydrocarbon partitioning was a clinical isolate obtained from M. Rask, Cedars-Sinai Medical Center, Los Angeles. The K99-positive strain of E. coli was a K 12 recombinant received from L. Myers, Veterinary Research Laboratory, Montana State University, who also supplied a monoclonal antibody against the K99 fimbrial antigen. Stock strains of all bacteria were stored in peptone-glycerol at $-20^{\circ} \mathrm{C}$.

Epithelial cell association. Henle 407 intestinal epithelial cells (ATCC CCL-6) were maintained in Eagle's Basal Medium with Hanks's Balanced Salts Solution containing fetal bovine serum $15 \%$, penicillin $50 \mu \mathrm{g} / \mathrm{ml}$ and streptomycin $50 \mu \mathrm{g} / \mathrm{ml}$. The cells were grown in tissue-culture flasks until the monolayer was at least $80 \%$ confluent. On the day before use, fresh medium without antibiotics was provided. For use, cells were washed twice with Dulbecco's phosphate-buffered saline without calcium (PBS) and harvested by scraping the monolayer off the flask wall. Cell clumps were dispersed by repeated aspiration. The cells were suspended in Eagle's Basal Medium and the number of viable cells was determined microscopically by trypan blue exclusion. The cell density of the suspension was adjusted to $5 \cdot 6 \times 10^{3} / \mathrm{ml}$ by dilution with Eagle's Basal Medium.

Bacteria were grown at room temperature for $48 \mathrm{~h}$ with constant mixing in a $0.13 \mathrm{M}$ phosphate-buffered salts medium containing: $\left(\mathrm{NH}_{4}\right)_{2} \mathrm{SO}_{4}, 0.1 \% ; \mathrm{MgSO}_{4} .7 \mathrm{H}_{2} 0,0.001 \% ; \mathrm{CaCl}_{2}$, $0.001 \% ; \mathrm{NaCl}, 0 \cdot 1 \%$; yeast extract, $0 \cdot 1 \%$; and $\left[{ }^{35} \mathrm{~S}\right]$ methionine, $20 \mu \mathrm{Ci} / \mathrm{ml}$. The medium had a $p \mathrm{H}$ of 7.6. Bacteria were harvested by centrifugation at $2800 \mathrm{~g}$ for $30 \mathrm{~min}$ at $20^{\circ} \mathrm{C}$ and resuspended in PBS. The bacteria were counted in a Petroff-Hausser chamber and the density was adjusted to $5 \times 10^{8} / \mathrm{ml}$ with PBS. The adjusted suspension $(0.2 \mathrm{ml})$ was added to $1.8 \mathrm{ml}$ of the Henle-cell suspension. A plate count of the bacterial suspension was performed to determine the number of bacteria per Henle cell.

The mixture was centrifuged at $920 \mathrm{~g}$ for $10 \mathrm{~min}$ at $20^{\circ} \mathrm{C}$ and then incubated at $35^{\circ} \mathrm{C}$ for 30 min. The pellet containing cells and bacteria was gently resuspended and the contents of the tube $(2.0 \mathrm{ml})$ were added to $25-30 \mathrm{ml}$ of PBS on a 5- $\mu \mathrm{m}$ Nucleopore membrane that had been pre-treated with $20-25 \mathrm{ml}$ of $1 \mathrm{~mm}$ ethylene glycol-bis-( $\beta$-amino-ethyl ether) N, N'tetraacetic acid (EGTA) in $2 \%$ peptone ( $p \mathrm{H} 8 \cdot 3$ ). After filtration under gravity an additional $100 \mathrm{ml}$ of PBS was added to rinse the membrane. Each test was performed in triplicate.

Control suspensions containing bacteria alone were prepared and filtered in a similar manner. The radioactivity of the bacteria was determined by filtering the suspensions through a $0 \cdot 4-\mu \mathrm{m}$ Nucleopore membrane. The background reading for broth was determined by centrifuging the suspension at $3700 \mathrm{~g}$ for $30 \mathrm{~min}$ and filtering the supernate.

Membranes were placed in scintillation vials with $10 \mathrm{ml}$ of Aquasol (New England Nuclear, Boston, MA) and radioactivity was determined by scintillation counting (Tri-Carb $460 \mathrm{CD}$ 
Liquid Scintillation System, Packard Instrument Co., Inc., Downers Grove, IL). Counts were converted to disintegrations/min by reference to an efficiency curve based on ${ }^{14} \mathrm{C}$. The radioactivity/bacterial cell was calculated and this volume was used to determine the average number of bacteria associated with each Henle cell.

Hydrophobic interaction chromatography. Cultures of Yersinia spp. were grown as described above. Bacteria were harvested by centrifugation and resuspended in $4 \mathrm{M} \mathrm{NaCl}$ in $10 \mathrm{~mm}$ phosphate buffer $\left(p \mathrm{H} \mathrm{7.2)}\right.$ to achieve a concentration of $c .10^{9}$ cells $/ \mathrm{ml}$. E. coli was grown on Minca agar (Guinee et al., 1977) at $35^{\circ} \mathrm{C}$ for $48 \mathrm{~h}$. Bacteria were scraped off the agar and suspended in $4 \mathrm{M} \mathrm{NaCl}$ to achieve a concentration of $c .10^{9}$ cells $/ \mathrm{ml}$.

Sepharose CL-48 and phenyl-Sepharose CL-48 (Pharmacia, Inc., Piscataway, NJ) were washed five times with equal volumes of $4 \mathrm{M} \mathrm{NaCl}$. A volume was added to a Pasteur pipette plugged with glass wool to provide a column of $20-25 \mathrm{~mm}$ after settling. The pipette was filled to the top with $4 \mathrm{M} \mathrm{NaCl}$ and allowed to drain. The bacterial suspension $(100 \mu \mathrm{l})$ was layered on the top of the column and $5 \mathrm{ml}$ of $4 \mathrm{M} \mathrm{NaCl}$ were added for elution. The number of bacteria added to the column and the number recovered in the eluate were determined by plate counts and the percentage adherent to the column was calculated.

Partitioning in an aqueous-hydrocarbon mixture. Cultures of Yersinia spp. were grown as described above. Bacteria were harvested by centrifugation and washed twice with $0.85 \% \mathrm{NaCl}$. The density of each bacterial suspension was adjusted photometrically to an absorbance of $1 \cdot 2-1.4$ at $400 \mathrm{~nm}$ (DMS 80 Spectrophotometer, Varian Associates, Mulgrave, Victoria, Australia). A control culture of $P$. mirabilis was grown on Trypticase Soy Agar supplemented with yeast extract $0.6 \%$ at $35^{\circ} \mathrm{C}$ for $24 \mathrm{~h}$. Bacteria were washed from the agar, centrifuged and washed twice with $0.85 \% \mathrm{NaCl}$.

Four $\mathrm{ml}$ of the bacterial suspension were added to an acid-washed glass test tube and the hydrocarbon (xylenes or hexadecane) was added. The tube contents were mixed on a vortex mixer for $1 \mathrm{~min}$ and then allowed to stand for $15 \mathrm{~min}$. The aqueous phase was removed from the tube and added to a cuvette. Results were expressed as percentage decrease in absorbance of the aqueous phase at $400 \mathrm{~nm}$.

Aggregation in ammonium sulphate. Cultures of Yersinia spp. and a control culture of $E$. coli were grown as described. Bacteria were harvested and suspended in $0.002 \mathrm{M}$ phosphate buffer $\left(\mathrm{pH} \mathrm{6.8)}\right.$ to achieve a concentration of $c .10^{9}$ cells $/ \mathrm{ml}$. Twenty-five $\mu \mathrm{l}$ of the suspension were added to $50 \mu \mathrm{l}$ of $\left(\mathrm{NH}_{4}\right)_{2} \mathrm{SO}_{4}$ solution in $0.002 \mathrm{M}$ phosphate buffer in a well slide. The concentrations of $\left(\mathrm{NH}_{4}\right)_{2} \mathrm{SO}_{4}$ started at $0.02 \mathrm{M}$ and increased in $0.02 \mathrm{M}$ increments to $0.20 \mathrm{M}$, and then in $0.20 \mathrm{~m}$ increments to $2.0 \mathrm{M}$. The slide was rocked for $2 \mathrm{~min}$ and aggregation was observed under a stereomicroscope.

\section{RESULTS}

\section{Epithelial cell association}

Six of the 11 strains of Yersinia exhibited a positive association with Henle epithelial cells (table). An average of 152 bacteria per Henle cell was observed with one strain and an average of $53( \pm 14)$ bacteria per Henle cell with the other five Henle-positive strains. To confirm that the increase in radioactivity observed in the presence of Henle cells was due to associated bacteria, an experiment was designed in which the Henle cells were first exposed to unlabelled bacteria ( $Y$. enterocolitica E736) then to radiolabelled bacteria of the same strain. In this case the radioactivity did not exceed the background reading observed with bacteria alone.

All strains of $Y$. enterocolitica exhibiting Henle-cell association also exhibited autoagglutination (Laird and Cavanaugh, 1980) and some other markers of virulence (Devenish and Schiemann, 1981; Schiemann et al., 1981; Karmali et al., 1982; Schiemann and Devenish, 1982). These strains behaved as Y. enterocolitica sensu stricto (Bercovier et al., 1980) in biochemical tests. Two of the Henle-negative strains 
were identified as $Y$. kristenseni and one as $Y$. intermedia. The remaining two Henle-negative strains were, unlike the Henle-positive strains, able to hydrolyse salicin at $35^{\circ} \mathrm{C}$ and aesculin at $22^{\circ} \mathrm{C}$ (Schiemann and Devenish, 1982).

\section{Hydrophobic interaction chromatography}

The E. coli K99 control culture showed $96 \%$ adsorption to phenyl-Sepharose, which was significantly higher than the $60 \%$ adsorption to Sepharose alone (table). Four of the 11 strains of Yersinia showed $>90 \%$ adsorption to phenyl-Sepharose, a level often taken to indicate hydrophobicity. For nine of the test strains, adsorption to phenyl-Sepharose was significantly higher than to Sepharose alone. Four of the six Henle-positive strains showed $>90 \%$ adsorption. Adsorption to phenyl-Sepharose and Sepharose was significantly different for the remaining two Henle-positive strains. Three of the five Henle-negative strains also showed differences in adsorption to phenyl-Sepharose and Sepharose. The difference observed with Y. kristenseni E709 was not statistically significant because of the low precision $(\mathrm{SD}=22.6)$ of the Sepharose results. There was no difference in adsorption to phenyl-Sepharose and Sepharose by $Y$. intermedia E814. Strains of Yersinia adhering to phenyl-Sepharose by

TABLE

Relationship of Henle-cell association to hydrophobicity in Yersinia spp.

\begin{tabular}{|c|c|c|c|c|c|}
\hline \multirow{2}{*}{$\begin{array}{c}\text { Test } \\
\text { strain } \\
\text { (serotype) }\end{array}$} & \multirow{2}{*}{$\begin{array}{c}\text { Number of } \\
\text { bacteria/ } \\
\text { Henle cell (SD) }\end{array}$} & \multicolumn{2}{|c|}{ Percentage adsorption (SD) } & \multirow{2}{*}{$\begin{array}{c}\text { Decrease in } \\
\text { absorbance* } \\
(\%)\end{array}$} & \multirow{2}{*}{$\begin{array}{c}\text { Lowest molarity } \\
\text { of }\left(\mathrm{NH}_{4}\right)_{2} \mathrm{SO}_{4} \\
\text { showing cell } \\
\text { aggregation }\end{array}$} \\
\hline & & Phenyl-Sepharose & Sepharose & & \\
\hline $\begin{array}{r}Y . \text { enterocolitica } \\
\text { E641 (O:5,27) }\end{array}$ & $152( \pm 42)$ & $97( \pm 0 \cdot 8)$ & $73( \pm 9 \cdot 3) \dagger$ & $95( \pm 0 \cdot 6$ & $1 \cdot 4$ \\
\hline $\begin{array}{c}\text { Y. enterocolitica } \\
\text { E661 (O:8) }\end{array}$ & $46( \pm 2 \cdot 9)$ & $87( \pm 5 \cdot 8)$ & $1 \cdot 2( \pm 2 \cdot 1) \dagger$ & $69( \pm 3 \cdot 5)$ & $1 \cdot 4$ \\
\hline $\begin{array}{l}\text { Y. enterocolitica } \\
\text { E663 }(0: 8)\end{array}$ & $55( \pm 8 \cdot 9)$ & $93( \pm 2 \cdot 4)$ & $21( \pm 15 \cdot 2) \dagger$ & $58( \pm 6 \cdot 8)$ & $1 \cdot 4$ \\
\hline $\begin{array}{c}\text { Y. enterocolitica } \\
\text { E736 }(\mathrm{O}: 21)\end{array}$ & $37( \pm 11 \cdot 5)$ & $82( \pm 5 \cdot 4)$ & $48( \pm 7 \cdot 2)^{\dagger}$ & $78( \pm 2 \cdot 2)$ & $1 \cdot 4$ \\
\hline $\begin{array}{c}\text { Y. enterocolitica } \\
\text { E739 }(\mathrm{O}: 3)\end{array}$ & $50( \pm 20 \cdot 2)$ & $94( \pm 1 \cdot 1)$ & $40( \pm 7 \cdot 2) \dagger$ & $60( \pm 4 \cdot 4)$ & NA \\
\hline $\begin{array}{l}\text { Y. enterocolitica } \\
\text { E887 (O:13) }\end{array}$ & $75( \pm 29 \cdot 7)$ & $93( \pm 3 \cdot 8)$ & $23( \pm 20 \cdot 8) \dagger$ & $88( \pm 2 \cdot 7)$ & $2 \cdot 0$ \\
\hline $\begin{array}{l}\text { Y. enterocolitica } \\
\text { E668 }(0: 6,30)\end{array}$ & $2( \pm 3 \cdot 6)$ & $84( \pm 11 \cdot 1)$ & $39( \pm 11 \cdot 4) \dagger$ & $51( \pm 5 \cdot 8)$ & $1 \cdot 2$ \\
\hline $\begin{array}{l}Y . \text { kristenseni } \\
\text { E709 }(\mathrm{O}: 12,26)\end{array}$ & 0 & $89( \pm 3 \cdot 3)$ & $54( \pm 22 \cdot 6)$ & $62( \pm 6 \cdot 0)$ & $1 \cdot 2$ \\
\hline $\begin{array}{l}Y . \text { enterocolitica } \\
\text { E770 }(0: 5)\end{array}$ & 0 & $65( \pm 4 \cdot 3)$ & $25( \pm 2 \cdot 2) \dagger$ & $6( \pm 5 \cdot 0)$ & $1 \cdot 2$ \\
\hline $\begin{array}{l}Y . \text { kristenseni } \\
\text { E812 }\end{array}$ & 0 & $70( \pm 5 \cdot 0)$ & $2( \pm 3 \cdot 1)^{\dagger}$ & $21( \pm 11 \cdot 1)$ & NA \\
\hline Y. intermedia E814 & 0 & $3( \pm 4 \cdot 4)$ & $7( \pm 11 \cdot 8)$ & $6( \pm 4 \cdot 8)$ & NA \\
\hline E. coli & NT & $96( \pm 0 \cdot 3)$ & $60( \pm 1 \cdot 3) \dagger$ & NT & $0 \cdot 02$ \\
\hline P. mirabilis & NT & NT & NT & $78( \pm 2 \cdot 5)$ & NT \\
\hline
\end{tabular}

$\mathrm{NA}=$ no aggregation observed in $2.0 \mathrm{M}$ ammonium sulphate. NT $=$ not tested.

* Decrease in absorbance at $400 \mathrm{~nm}$ of aqueous phase after separation of a mixture of bacterial suspension $4.0 \mathrm{ml}$ and hexadecane $0.5 \mathrm{ml}$.

$\dagger$ Difference between phenyl-Sepharose and Sepharose statistically significant by Student's $t$ test for independent means $(\mathrm{p}=0.05)$. 
the column technique did not do so when bacteria and phenyl-Sepharose were mixed in a vial and allowed to settle. Under these conditions, there was no difference in numbers of bacteria in supernatant fluids from phenyl-Sepharose, Sepharose and a buffer control.

\section{Hydrocarbon partitioning}

A preliminary experiment was performed to determine the influence of hydrocarbon concentration and type of hydrocarbon on partitioning in an aqueous-hydrocarbon system. $P$. mirabilis was selected as a control organism because a previous report indicated that it was hydrophobic when tested by this technique (Rosenberg et al., 1982). The results showed that the degree of partitioning of $P$. mirabilis was greater with xylenes than with hexadecane, and was related to the volume of hydrocarbon added (fig.). In contrast, $Y$. enterocolitica E641 (Henle-positive) showed a high degree of partitioning that was unrelated to type or volume of hydrocarbon. For the remaining tests, $0.5 \mathrm{ml}$ of hexadecane was used with $4.0 \mathrm{ml}$ of bacterial suspension.

The control culture of $P$. mirabilis showed $78 \%$ decrease in absorbance of the aqueous phase (table). Only three strains of $Y$. enterocolitica (all Henle-positive) exhibited a decrease in absorbance $\geqslant 78 \%$. Three Henle-negative strains showed a very

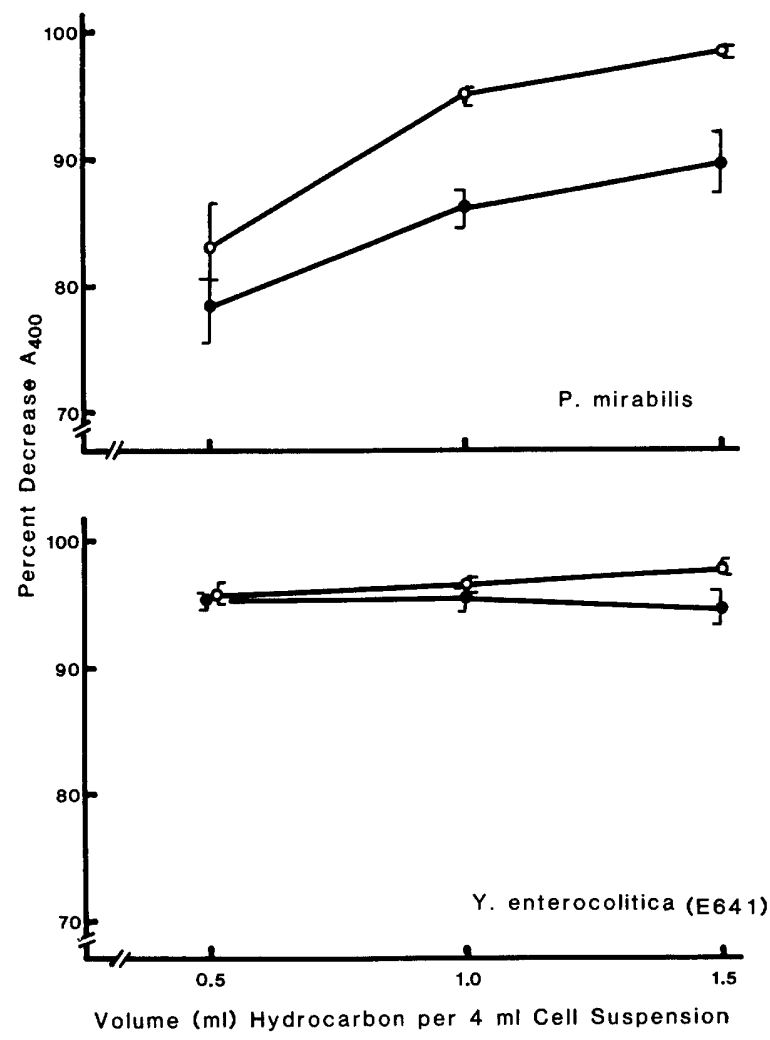

FIG.-Partitioning of bacterial cells in mixtures of saline and hexadecane (e) or saline and xylenes (O) expressed as percentage change in absorbance of the aqueous phase at $400 \mathrm{~nm}$. Arithmetic mean and range for three determinations at each solvent volume are shown. 
low degree of partitioning. The remaining three Henle-positive strains and two Henle-negative strains exhibited similar decreases in absorbance.

\section{Aggregation in ammonium sulphate}

The culture of $E$. coli exhibited aggregation in $0.02 \mathrm{M}$ ammonium sulphate, whereas the lowest concentration of ammonium sulphate in which any strain of Yersinia showed aggregation was $1 \cdot 2 \mathrm{~m}$ (table).

\section{DisCUSSION}

Previous studies established that pathogenic strains of $Y$. enterocolitica can be distinguished by their ability to associate with epithelial cells in vitro (Lee et al., 1977; Une, 1977; Okamoto et al., 1980; Devenish and Schiemann, 1981; Schiemann et al., 1981; Schiemann and Devenish, 1982). In this study, strains of Y. enterocolitica displaying other markers of virulence associated with Henle 407 epithelial cells, whereas strains lacking these markers did not.

Several reports suggest, mostly by use of semi-quantitative criteria, that epithelial cell association is related to bacterial cell hydrophobicity, and that hydrophobicity is in turn dependent on the presence of fimbriae (Smyth et al., 1978; Wadstrom et al., 1980; Lindhal et al., 1981; Rosenberg et al., 1981; Rosenberg et al., 1982; Faris et al., 1983). Using hydrophobic interaction chromatography to measure hydrophobicity, we had difficulty in interpreting quantitative results. Henle-positive strains of Yersinia could be differentiated from Henle-negative strains neither by applying a criterion based on a certain level of adsorption to phenyl-Sepharose, nor by the difference between adsorption to substituted and unsubstituted gels. Although all Henle-positive strains were hydrophobic by one or other of these criteria, so were four of the five Henle-negative strains.

When hydrophobicity was measured by the degree of partitioning in an aqueoushexadecane mixture, a clearer relationship to Henle-cell association was observed. Three of the five Henle-negative strains were non-hydrophobic and all Henle-positive strains were hydrophobic by this technique. However, two Henle-negative strains were as hydrophobic as Henle-positive strains. Tests of aggregation in ammonium sulphate indicated that the hydrophobicity observed in Yersinia spp. by the other two techniques was not related to the presence of protein structures as suggested by other workers (Lindahl et al., 1981; Faris et al., 1983). Hydrophobicity can be conferred by outer-membrane structures other than fimbrial proteins, such as lipopolysaccharides, phospholipids, lipoproteins and outer-membrane proteins.

Strains of $Y$. enterocolitica that were capable of association with Henle 407 epithelial cells were also hydrophobic. However, the converse was not true. This indicates that other factors are necessary for the association of $Y$. enterocolitca with epithelial cells.

This work was supported by Public Health Service grant number AM33510-01 from the National Institute of Arthritis, Diabetes, Digestive and Kidney Diseases, and the Montana Agricultural Experiment Station.

\section{REFERENCES}

Bercovier H, Brenner D J, Ursing J, Steigerwalt A G, Fanning G R, Alonso J M, Carter G P, Mollaret H H 1980 Characterization of Yersinia enterocolitica sensu stricto. Current Microbiology 4:201-206. 
Devenish J A, Schiemann D A 1981 HeLa cell infection by Yersinia enterocolitica: evidence for lack of intracellular multiplication and development of a new procedure for quantitative expression of infectivity. Infection and Immunity 32:48-55.

Faris A, Lindahl M, Ljungh A, Old D C, Wadstrom T 1983 Auto-aggregating Yersinia enterocolitica express surface fimbriae with surface hydrophobicity. Journal of Applied Bacteriology 55:97-100.

Guinee P A M, Veldkamp J, Jansen W H 1977 Improved Minca medium for the detection of K99 antigen in calf enterotoxigenic strains of Escherichia coli. Infection and Immunity 15:676-678.

Karmali M A, Toma S, Schiemann D A, Ein S H 1982 Infection caused by Yersinia enterocolitica serotype O:21. Journal of Clinical Microbiology 15:596-598.

Lachica R V, Zink D L 1984 Plasmid-associated cell surface charge and hydrophobicity of Yersinia enterocolitica. Infection and Immunity 44:540-543.

Laird W J, Cavanaugh D C 1980 Correlation of autoagglutination and virulence of Yersiniae. Journal of Clinical Microbiology 11:430-432.

Lee W H, McGrath P P, Carter P H, Eide E L 1977 The ability of some Yersinia enterocolitica strains to invade HeLa cells. Canadian Journal of Microbiology 23:1714-1722.

Lindahl M, Faris A, Wadstrom T, Hjerten S 1981 A new test based on 'salting out' to measure relative surface hydrophobicity of bacterial cells. Biochimica et Biophysica Acta 677:471-476.

Okamoto K, Inuoe T, Ichikawa H, Kawamoto Y, Hara S, Miyama A 1980 Adherence of Yersinia enterocolitica to mammalian epithelial cell lines. Microbiology and Immunology 24:1013-1022.

Old D C, Robertson J 1981 Adherence of fimbriate and non-fimbriate strains of Yersinia enterocolitica to human epithelial cells. Microbiology and Immunology 25:993-998.

Rahimian F, Evans Z A 1981 Pili production and HeLa cell invasiveness by Yersinia enterocolitica. Abstracts of the Annual Meeting of the American Society for Microbiology p 23.

Rosenberg M, Bayer E A, DeLarea J, Rosenberg E 1982a Role of thin fimbriae in adherence and growth of Acinetobacter calcoaceticus RAG-1 on hexadecane. Applied and Environmental Microbiology 44:929-937.

Rosenberg M, Gutnick D, Rosenberg E 1980 Adherence of bacteria to hydrocarbons: a simple method for measuring cell-surface hydrophobicity. FEMS Microbiology Letters 9:29-33.

Rosenberg M, Perry A, Bayer E A, Gutnick D L, Rosenberg E, Ofek I 1981 Adherence of Acinetobacter calcoaceticus RAG-1 to human epithelial cells and to hexadecane. Infection and Immunity 33:29-33.

Rosenberg M, Rottem S, Rosenberg E $1982 b$ Cell surface hydrophobicity of smooth and rough Proteus mirabilis strains as determined by adherence to hydrocarbons. FEMS Microbiology Letters 13:167-169.

Schiemann D A, Devenish J A 1981 Relationship of HeLa cell infectivity to virulence in Yersinia enterocolitica. Abstracts of the Annual Meeting of the American Society for Microbiology p 23.

Schiemann D A, Devenish J A 1982 Relationship of HeLa cell infectivity to biochemical, serological, and virulence characteristics of Yersinia enterocolitica. Infection and Immunity 35:497-506.

Schiemann D A, Devenish J A, Toma S 1981 Characteristics of virulence in human isolates of Yersinia enterocolitica. Infection and Immunity 32:400-403.

Smyth C J, Jonsson P, Olsson E, Soderlind O, Rosengren J, Hjerten S, Wadstrom T 1978 Difference in hydrophobic surface characteristics of porcine enteropathogenic Escherichia coli with or without $\mathrm{K} 88$ antigen as revealed by hydrophobic interaction chromatography. Infection and Immunity 22:462-472.

Une, T 1977 Studies on the pathogenicity of Yersinia enterocolitica. II. Interaction with cultured cells in vitro. Microbiology and Immunology 21:365-377.

Wadstrom T, Faris A, Freer J, Habte D, Hallberg D, Ljungh A 1980 Hydrophobic surface properties of enterotoxigenic Escherichia coli (ETEC) with different colonization factors (CFA/I, CFA/II, K88 and K99) and attachment to intestinal epithelial cells. Scandinavian Journal of Infectious Diseases Suppl no. 24:148-153. 